\title{
Canine babesiosis in northern Portugal and molecular characterization of vector-borne co-infections
}

\author{
Luís Cardoso*+1,2, Yael Yisaschar-Mekuzas³, Filipa T Rodrigues ${ }^{4}$, Álvaro Costa5 ${ }^{5}$ João Machado ${ }^{1}$, Duarte Diz-Lopes ${ }^{4}$ and \\ Gad Baneth ${ }^{3}$
}

\begin{abstract}
Background: Protozoa and bacteria transmitted by arthropods, including ticks and phlebotomine sand flies, may cause a wide range of canine vector-borne diseases. Dogs can be simultaneously or sequentially infected with multiple pathogens. Canine babesiosis caused by Babesia canis canis and Babesia canis vogeli is known to occur in Portugal. This study assessed, by means of blood smear examination, PCR and DNA nucleotide sequencing, the presence of Babesia spp. and co-infecting agents Leishmania, Anaplasma/Ehrlichia and Hepatozoon in 45 dogs from northern Portugal clinically suspected of babesiosis.

Results: Forty-four dogs (98\%) had infection with B. canis canis and one with B. canis vogeli. Co-infections were detected in nine animals (20\%). Eight dogs were found infected with two vector-borne agents: six with B. canis canis and Leishmania infantum; one with B. canis canis and Ehrlichia canis; and one with B. canis canis and Hepatozoon canis. Another dog was infected with three vector-borne pathogens: B. canis vogeli, E. canis and L. infantum. Overall, L. infantum was found in seven (16\%), E. canis in two (4\%), and H. canis in one (2\%) out of the 45 dogs with babesiosis. Almost $90 \%$ of the 45 cases of canine babesiosis were diagnosed in the colder months of October (18\%), November (27\%), December (20\%), February (13\%) and March (9\%). Co-infections were detected in February, March, April, May, October and November. Twenty-two (50\%) out of 44 dogs infected with B. canis were found infested by ticks including Dermacentor spp., Ixodes spp. and Rhipicephalus sanguineus. Mortality (9\%) included two co-infected dogs that died spontaneously and two with single infections that were euthanized.

Conclusions: Babesia canis canis is the main etiological agent of canine babesiosis in northern Portugal. A higher sensitivity of Babesia spp. detection was obtained with PCR assays, compared to the observation of blood smears. Twenty percent of the dogs were co-infected with L. infantum, E. canis or H. canis. Furthermore, this is the first molecular identification of $H$. canis in dogs from northern Portugal.
\end{abstract}

\section{Background}

A large variety of protozoa and bacteria transmitted by arthropods, including ixodid ticks and phlebotomine sand flies, may cause diseases in dogs and other vertebrate hosts [1,2]. Canine piroplasmosis is caused by several tick-borne Babesia and Theileria protozoal haemoparasites (termed piroplasms) and represents a pathological condition with significant veterinary medi-

\footnotetext{
*Correspondence: Icardoso@utad.pt

1 Department of Veterinary Sciences, University of Trás-os-Montes e Alto Douro, Vila Real, Portugal

+ Contributed equally

Full list of author information is available at the end of the article
}

cal importance in many parts of the world [3]. Mainly depending on the piroplasm species or subspecies, the effects of infection in dogs may range from a subclinical condition to severe and even fatal illness. Clinical abnormalities associated with piroplasmosis frequently comprise lethargy, anorexia, pale mucous membranes, icterus, hyperthermia, haemolytic anaemia, haemoglobinuria and thrombocytopenia $[4,5]$. Other factors, such as the canine host age and immunity [6], together with concomitant infections or diseases, also play a role in the potentially variable pathogenicity of the disease [7]. 
Morphological appearance in the erythrocytes and especially molecular analysis have allowed the differentiation of several large $(3-5 \mu \mathrm{m})$ and small $(0.5-2.5 \mu \mathrm{m})$ piroplasms of dogs [3]. In Europe, the causative agents of canine babesiosis include large Babesia canis canis, a subspecies transmitted by the tick Dermacentor reticulatus which causes a mild to severe disease, and B. canis vogeli, transmitted by Rhipicephalus sanguineus [8-11]. Babesia canis vogeli, the less virulent subspecies of B. canis, is also present in tropical and subtropical areas of Africa [12], Asia [13], Australia [14], North and South America $[15,16]$. The most virulent of the three subspecies, $B$. canis rossi, has been reported only in central and southern Africa [4,17]. Furthermore, another large yet unnamed Babesia sp., genetically related to Babesia bigemina of cattle, has been reported in dogs with clinical signs of babesiosis in North Carolina $[18,19]$.

Small Theileria annae, a Babesia microti-like piroplasm [20] endemic in northwestern Spain [21], and Babesia gibsoni have also been detected as agents of babesial disease in European dogs [22-24]. Outside Europe, T. annae has been detected in one dog from Mississipi [25]. Babesia gibsoni has a wider distribution, with infections reported primarily from Asia [13] but also from America $[15,26]$ and Australia [27]. One other genetically distinct small piroplasm species is recognised to cause canine babesiosis: Babesia conradae in southern California [28]. Furthermore, DNA of large Babesia caballi [24] and small Theileria equi [24,29] and Theileria annulata [30], in Europe, and an unnamed Theileria sp., in South Africa [31], have been detected in dogs, but their role in canine piroplasmosis needs to be confirmed.

The geographical distribution of canine piroplasms is largely determined by the ecological ranges of their vector arthropods [32]. Epidemiological surveillance of disease occurrence and prevalence is required to map local risk and forecast vector-borne infection scenarios. Canine babesiosis caused by large piroplasms is known to occur in northeastern Portugal [33], and both B. canis canis and $B$. canis vogeli have recently been identified in some naturally infected dogs from this area [34]. In areas where canine vector-borne diseases (CVBD) are endemic, dogs can be simultaneously or sequentially infected with more than one vector-borne agent, depending on the presence and abundance of arthropod vectors [1]. Leishmania infantum [35] and the rickettsiae Anaplasma platys and Ehrlichia canis are also proven agents of CVBD in northern Portugal [36]. The sand fly season runs from May to October in the Douro subregion of northern Portugal: Phlebotomus perniciosus and Phlebotomus ariasi, vectors of Leishmania, are most abundant in July and September, respectively [37]. Ticks of the species $D$. reticulatus and $R$. sanguineus have been found to infest dogs in northeastern Portugal [38-40]. In addition to transmitting B. canis vogeli and E. canis, and presumably A. platys, $R$. sanguineus is also the main vector for protozoan Hepatozoon canis in Europe [41,42]. This study assessed the presence of Babesia spp. and the co-infecting pathogens Leishmania, Anaplasma/Ehrlichia and Hepatozoon in dogs from northern Portugal clinically suspected of babesiosis by means of blood smear examination, PCR and DNA nucleotide sequencing.

\section{Methods}

\section{Animals and samples}

Forty-five dogs from Alto Trás-os-Montes and Douro (northern Portugal) suspected of babesiosis, between October 2007 and March 2009, were included in this study. The two subregions of Alto Trás-os-Montes (north) and Douro (south) cover a total area of 12,282 sq. $\mathrm{km}$ and are bordered by Spain to the north and east. The terrain is hilly, and agriculture is the main source of occupation and income. No history of travel to southern Portugal or to Spain was obtained for any of the 45 dogs. After recording the dog's signalment, each animal was physically examined and blood samples were collected from the ear tip to prepare glass slide smears and to assess microhaematocrit (HCT). The thin smears were air-dried, fixed with methanol, Giemsa-stained and then examined under light microscopy (magnification 1000x; 100 fields) for detection of babesial piroplasms and other possible infective agents. Additional samples of peripheral or venous blood were spotted onto individual filter papers $(7.5 \mathrm{~cm} \times 2.5 \mathrm{~cm}$; GB 002 Schleicher and Schuell, Dassel, Germany) allowed to air-dry and stored at $-20^{\circ} \mathrm{C}$ until further use. Dogs were also examined for the presence of infesting ticks. The anti-babesial treatment administered was recorded and the disease outcome followed.

\section{DNA extraction}

Filter paper portions, corresponding to approximately 20 $\mu \mathrm{l}$ of spotted blood, were cut out by use of individual sterile scalpel blades and put into sterile tubes for DNA extraction [43]. DNA was extracted by adding $300 \mu \mathrm{l}$ of lysis buffer [50 mM NaCl, $50 \mathrm{mM}$ Tris, $10 \mathrm{mM}$ EDTA (pH 8.0)], proteinase $\mathrm{K}$ to a final concentration of $250 \mu \mathrm{g} / \mathrm{ml}$ and Triton X-100 (20\%) to a final concentration of $1 \%$. Following a $2 \mathrm{~h}$ incubation at $56^{\circ} \mathrm{C}$ and an inactivation of proteinase $\mathrm{K}$ at $90^{\circ} \mathrm{C}$ for $10 \mathrm{~min}, 300 \mu \mathrm{l}$ of phenol (75\%), chloroform (24\%) and isoamylalcohol (1\%) mixture were added, vortexed and centrifuged $(12,000 \times g)$ for $4 \mathrm{~min}$. The supernatant was collected and $300 \mu \mathrm{l}$ of a mixture of phenol (50\%), chloroform (48\%) and isoamylalcohol (2\%) were added, vortexed and centrifuged $(12,000 \times g)$ for 4 min. The supernatant was collected and $300 \mu \mathrm{l}$ of a mix- 
ture of chloroform (96\%) and isoamylalcohol (4\%) were added, vortexed and centrifuged $(12,000 \times g)$ for $4 \mathrm{~min}$. The supernatant was collected, and 1:10 volume of $\mathrm{Na}$ acetate $(3 \mathrm{M})$ and one volume of ice cold $100 \%$ isopropanol $\left(-20^{\circ} \mathrm{C}\right)$ were added and incubated over night at $-20^{\circ} \mathrm{C}$. Following centrifugation $(14,000 \times g)$ at $4^{\circ} \mathrm{C}$ for $30 \mathrm{~min}$, the supernatant was discarded and the pellet was washed with $150 \mu \mathrm{l}$ of ethanol $\left(75 \%,-20^{\circ} \mathrm{C}\right)$ and centrifuged $\left(13,000 \times g 4^{\circ} \mathrm{C}\right)$ for $15 \mathrm{~min}$. The supernatant was discarded and the pellet was air-dried. The DNA was then hydrated with $30 \mu \mathrm{l}$ of double-distilled $\mathrm{H}_{2} \mathrm{O}$ for $1 \mathrm{~h}$ at $50^{\circ} \mathrm{C}$.

\section{PCR assays for Babesia, Anaplasma/Ehrlichia, Hepatozoon and Leishmania}

Primers PIRO-A and PIRO-B (Table 1) were used to amplify an approximate 408 bp fragment of the $18 \mathrm{~S}$ ribosomal RNA (rRNA) gene of Babesia spp. by PCR [44]. Amplification was done under the following conditions: $94^{\circ} \mathrm{C}$ for $1 \mathrm{~min}$ followed by 39 cycles of $94^{\circ} \mathrm{C}$ for $45 \mathrm{sec}$, $62^{\circ} \mathrm{C}$ for $45 \mathrm{sec}$ and $72^{\circ} \mathrm{C}$ for $45 \mathrm{sec}$.

Primers EHR16SD and EHR16SR (Table 1) were used to amplify an approximate $345 \mathrm{bp}$ fragment of the Ehrlichia and Anaplasma genera 16S rRNA gene [45]. PCR amplification was performed under the following conditions: $95^{\circ} \mathrm{C}$ for $5 \mathrm{~min} ; 40$ cycles of $94^{\circ} \mathrm{C}$ for $30 \mathrm{sec}, 55^{\circ} \mathrm{C}$ for $30 \mathrm{sec}$ and $72^{\circ} \mathrm{C}$ for $90 \mathrm{sec}$; then final extension at $72^{\circ} \mathrm{C}$ for $5 \mathrm{~min}$ [46].

PCR for the detection of Hepatozoon was performed using primers (125 nM each) HEP-F and HEP-R $[47,48]$
(Table 1). The following conditions were used to amplify a partial $666 \mathrm{bp}$ fragment of the $18 \mathrm{~S}$ rRNA gene sequence of Hepatozoon spp.: $95^{\circ} \mathrm{C}$ for $5 \mathrm{~min} ; 35$ cycles of $95^{\circ} \mathrm{C}$ for $20 \mathrm{sec}, 57^{\circ} \mathrm{C}$ for $30 \mathrm{sec}$ and $72^{\circ} \mathrm{C}$ for $90 \mathrm{sec}$; and $72^{\circ} \mathrm{C}$ for 5 min. PCR was performed using Syntezza PCR-Ready High Specificity (Syntezza Bioscience, Israel).

A 265 bp fragment within the internal transcribed spacer 1 (ITS1) region of the L. infantum rRNA operon was amplified by real-time PCR using the primers ITS219F and ITS-219R (Table 1) and then evaluated by high resolution melt (HRM) analysis [49]. The PCR reaction was performed in a total volume of $20 \mu \mathrm{l}$ containing $5 \mu \mathrm{l}$ DNA, $40 \mathrm{nM}$ of each primer, $10 \mu \mathrm{l}$ Thermo-start PCR Master Mix (Thermo-start ABgene, Rochester, NY, USA), $0.6 \mu \mathrm{l}$ 100-fold diluted SYTO9 (Invitrogen, Carlsbad, CA, USA), and sterile, DNase/RNase-free water (Sigma, St. Louis, MO, USA) using a Rotor-Gene 6000 real-time PCR machine (Corbett Life Science). Initial denaturation for 15 min at $95^{\circ} \mathrm{C}$ was followed by 40 cycles of denaturation at $5 \mathrm{sec}$ at $95^{\circ} \mathrm{C}$ per cycle, annealing and extension for 30 sec at $57^{\circ} \mathrm{C}$, and final extension for $1 \mathrm{sec}$ at $76^{\circ} \mathrm{C}$. This was followed by a conventional melting step from $60^{\circ} \mathrm{C}$ to $95^{\circ} \mathrm{C}$ at $1^{\circ} \mathrm{C} / \mathrm{sec}$, after which the temperature was slowly decreased from 90 to $50^{\circ} \mathrm{C}\left(1^{\circ} \mathrm{C} / \mathrm{sec}\right)$ to allow re-annealing. In the final step, HRM analysis was carried out increasing the temperature from $75^{\circ} \mathrm{C}$ to $90^{\circ} \mathrm{C}$ at $0.4^{\circ} \mathrm{C} /$ sec increments [49].

Positive B. canis, E. canis, $H$. canis and L. infantum DNA control samples from the blood of naturally infected dogs negative by PCR for other pathogens, and

Table 1: Primer sets for the PCR amplification and sequencing of vector-borne infective agents used in the study

\begin{tabular}{|c|c|c|}
\hline Agent & Primers & Reference(s) \\
\hline Babesia spp. & $\begin{array}{l}\text { PIRO-A: 5'-AAT ACC CAA TCC TGA CAC } \\
\text { AGG G-3' } \\
\text { PIRO-B: 5'-TTA AAT ACG AAT GCC CCC } \\
\text { AAC-3' }\end{array}$ & {$[44]$} \\
\hline Anaplasma spp./Ehrlichia spp. & $\begin{array}{l}\text { EHR16SD: 5'-GGT ACC YAC AGA AGA AGT } \\
\text { CC-3' } \\
\text { EHR16SR: 5'-TAG CAC TCA TCG TIT ACA } \\
\text { GC-3' }\end{array}$ & {$[45,46]$} \\
\hline Hepatozoon spp. & $\begin{array}{l}\text { HEP-F: 5'-ATA CAT GAG CAA AAT CTC AAC- } \\
\text { 3' } \\
\text { HEP-R: 5'-CTT ATT ATT CCA TGC TGC AG-3' }\end{array}$ & {$[47,48]$} \\
\hline Leishmania spp. & $\begin{array}{l}\text { ITS-219F: 5'-AGC TGG ATC ATT TTC CGA } \\
\text { TG-3' } \\
\text { ITS-219R: 5'-ATC GCG ACA CGT TAT GTG } \\
\text { AG-3' }\end{array}$ & {$[49]$} \\
\hline
\end{tabular}


negative DNA controls from colony-bred dogs negative by PCR for vector-borne pathogens were run with each corresponding PCR reaction.

\section{Sequencing}

DNA sequencing was performed at the Center for Genomics Technologies, Hebrew University of Jerusalem. Obtained DNA sequences were evaluated with ChromasPro software version 1.33 and compared for similarity to sequences in GenBank, using the BLAST program hosted by NCBI, National Institutes of Health, USA http:/ /www.ncbi.nlm.nih.gov.

\section{Statistical analysis}

The Chi-squared or Fisher's exact tests were used to compare proportions. Differences between independent groups were analyzed with the Mann-Whitney $U$ test [50]. Analyses were performed with SPSS 10.0 software for Windows, with a probability $(p)$ value $<0.05$ as statistically significant.

\section{Results}

The 45 dogs suspected of having babesiosis consisted of 24 males and 21 females. Age was not determined for seven dogs; in the remaining 38 animals it ranged from 2 months to 14 years (median value of 3.0 years [interquartile range: $1.1-4.8]$ ). There were $28 \mathrm{dogs}$ from nine defined breeds and 16 mongrels; breed was not determined for one dog. The most represented breeds were Podengo $(n=17)$ and the Brittany $(n=3)$.

The clinical signs found on physical examination in the 38 dogs were: lethargy $(n=24 ; 63 \%)$, red urine $(n=19$; $50 \%)$, hyperthermia $(n=18 ; 47 \%)$, anorexia $(n=17 ; 45 \%)$, pale mucous membranes $(\mathrm{n}=17 ; 45 \%)$, hypothermia $(\mathrm{n}=$ 9; $24 \%)$, yellow mucous membranes $(n=5 ; 13 \%)$, vomiting $(\mathrm{n}=4 ; 11 \%)$, abdominal pain $(\mathrm{n}=3 ; 8 \%)$, ataxia $(\mathrm{n}=2$; $5 \%)$, uterine discharge $(n=2 ; 5 \%)$, cough $(n=1 ; 3 \%)$, gingival petechiae $(\mathrm{n}=1 ; 3 \%)$ and ocular discharge $(\mathrm{n}=1$, $3 \%)$. Blood tests showed that 26 (79\%) out of 33 dogs were anaemic, with a HCT value below the reference interval (37-55\%). Data on physical examination were not determined in six and HCT was not evaluated in 12 out of the 45 dogs. Peripheral blood smear evaluation showed intraerythrocytic piroplasms morphologically compatible with $B$. canis (3-5 $\mu \mathrm{m}$ long and mainly occurring in pairs or single ring shapes) in 41 (91\%) of the 45 clinically suspected dogs. Presence of other infective agents could not be confirmed by microscopy of blood smears. Those 41 dogs and the remaining four suspected animals were all found positive for Babesia spp. by PCR. Further sequence analysis revealed that 44 dogs (98\%) were infected with $B$. canis canis (98-100\% relatedness to the GenBank closest sequence) and one with $B$. canis vogeli (100\% relatedness).
Results concerning the observation of large babesial parasites in smears, and PCR amplification with sequencing of Babesia and co-infecting Anaplasma/Ehrlichia, Hepatozoon or Leishmania agents are shown in Table 2. Thirty-six dogs were found infected only with B. canis canis, whereas co-infections were detected in nine dogs (20\%). Eight dogs were found infected with two vectorborne agents: six dogs with $B$. canis canis and L. infantum; one $\operatorname{dog}$ with $B$. canis canis and E. canis; and one dog with $B$. canis canis and $H$. canis. Another dog was found infected with three vector-borne organisms: $B$. canis vogeli, E. canis and L. infantum. Overall, L. infantum was found in seven dogs (16\%), E. canis in two dogs (4\%), and $H$. canis was found in one (2\%) out of the 45 dogs diagnosed with babesiosis.

Monthly distribution of the 45 observed cases of canine babesiosis was as follows: January $(\mathrm{n}=2)$, February $(\mathrm{n}=$ $6)$, March $(n=4)$, April $(n=1)$, May $(n=1)$, July $(n=1)$, September $(n=1)$, October $(n=8)$, November $(n=12)$ and December $(n=9)$. No cases were observed during June or August. Co-infection cases were detected in February, March, April, May, October and November (Figure 1 and Table 3 ).

Ticks were detected on 22 dogs and tick identification was performed in 10 of these animals. Dermacentor spp. found on four dogs infected with B. canis canis, and Ixodes spp. on four other dogs also infected with B. canis canis. Rhipicephalus sanguineus was present on the dog found co-infected with B. canis vogeli, E. canis and L. infantum. Another dog was co-infested with Dermacentor spp. and R. sanguineus and infected with B. canis canis. Ticks were not detected on 22 dogs and information from one animal was not determined. Twenty-two (50\%) out of 44 dogs infected with B. canis were found infested by ticks; and seven (78\%) out of nine dogs with co-infections had ticks.

Table 3 provides information on gender, breed, age, clinical signs, HCT, detected vector-borne agents, presence of ticks and month of sampling for the nine dogs found co-infected. Differences between HCT values in a group of eight co-infected (B. canis canis and L. infantum, E. canis or H. canis) and another group of 25 dogs not found co-infected (infected solely with B. canis canis) were not statistically significant (Mann-Whitney U test [MWU]; $p=0.449)$; the differences in HCT between a group of five dogs co-infected with $B$. canis canis and $L$. infantum and those 25 dogs not found co-infected were also not significant (MWU; $p=0.504$ ). The same was true for age differences between eight co-infected and 30 dogs not found co-infected (MWU; $p=0.971$ ); and for differences between age in five dogs co-infected with $B$. canis canis and L. infantum and in those 30 dogs solely infected with B. canis canis (MWU; $p=0.409$ ). No significant dif- 
Table 2: Comparison of results from blood smear examination, PCR and sequence analysis in 45 dogs suspected of babesiosis.

\begin{tabular}{|c|c|c|c|}
\hline \multirow[t]{2}{*}{ Blood smear } & \multicolumn{2}{|l|}{ PCR and sequencing } & \multirow[t]{2}{*}{ Dogs (n) } \\
\hline & Babesia spp. & Co-infection & \\
\hline \multirow[t]{5}{*}{ Large piroplasms } & B. canis canis $(98-100 \%)$ & Negative & 32 \\
\hline & B. canis canis $(99-100 \%)$ & L. infantum (99-100\%) & 6 \\
\hline & B. canis canis $(99 \%)$ & E. canis $(100 \%)$ & 1 \\
\hline & & H. canis $(99 \%)$ & 1 \\
\hline & B. canis vogeli $(99 \%)$ & $\begin{array}{l}\text { E. canis }(100 \%) \text { and L. infantum } \\
(99 \%)\end{array}$ & 1 \\
\hline Piroplasms not found & B. canis canis $(100 \%)$ & Negative & 4 \\
\hline
\end{tabular}

Percentage values refer to species or subspecies relatedness to the GenBank closest sequences.

ference, although close to significance, was observed when comparing the proportions of co-infected mongrel dogs $(6 / 16 ; 37.5 \%)$ and that of co-infected defined breed animals $(3 / 28 ; 10.7 \%)$ (Fisher's exact test; $p=0.053)$. Statistically significant differences were not found upon comparison of proportions of co-infected male (6/24; $25 \%)$ and co-infected female dogs $(3 / 21 ; 14.3 \%)$; or coinfected dogs among those infested with ticks (7/22; $31.6 \%)$ and co-infected dogs among those with no ticks $(2 / 22 ; 9.1 \%)$.

Of the 45 dogs diagnosed with babesiosis, four (9\%) died. Despite treatment with imidocarb dipropionate, two dogs died (22\%) out of the nine found co-infected (Table 3). One of these animals was found infected with B. canis vogeli, E. canis and L. infantum; and the other one with $B$. canis canis and L. infantum. Two other dogs with babesiosis were subject to euthanasia as requested by their owners. Molecular analysis later revealed infection with B. canis canis in these two animals. Forty-one dogs - including seven co-infected with B. canis canis and $L$. infantum, E. canis or $H$. canis and 34 with single infection (only B. canis canis) - clinically recovered after treatment with imidocarb dipropionate.

\section{Discussion}

In this study, babesiosis in northern Portugal was found to be caused predominantly by infection with $B$. canis canis, with $L$. infantum as the most prevalent co-infecting agent. Although ticks were found only on approximately half the dogs with babesiosis, a considerable proportion of the co-infected dogs were infested by ticks (78\%). In addition, canine babesiosis was diagnosed mainly from October to March, when climate conditions favour the activity of Dermacentor spp. ticks [38]. In agreement with previous studies $[34,36]$, molecular confirmation of the presence of vector-borne pathogens in northern Portugal has been reestablished for B. canis vogeli and E. canis. In addition, to our best knowledge, this is the first report of molecular identification of $H$. canis in dogs from northern Portugal. Based on the observation of $H$. canis gamonts in neutrophils, it had been previously assumed that $H$. canis is the species involved in canine infection, but genetic characterization was not available at the species level [40].

Babesia canis canis was detected in $98 \%$ of the 45 cases of canine babesiosis. This could be due to a higher prevalence of infected dogs or tick vectors in the study area, in comparison to $B$. canis vogeli, or to its more virulent nature. Due to the severity of clinical presentation, as compared with the relatively milder signs induced by $B$. canis vogeli [7], dogs infected with $B$. canis canis would potentially be brought in more often for veterinary consultation [34]. No comparisons were done between the dogs found infected with each one of the two subspecies of $B$. canis, because there was only one animal found infected with $B$. canis vogeli. An investigation of 164 Italian dogs suspected of tick-borne disease found $B$. canis canis in 34 and B. canis vogeli in 11 different cases [51]. This same study showed that clinical cases with $B$. canis vogeli infection did not present a homogenous clinicopathological pattern as observed in the clinical cases of infection with $B$. canis canis. Furthermore, in these dogs from Italy, B. canis vogeli infections were found in three puppies (1-2 months) associated with severe haemolytic anaemia (fatal disease in one case) but with no reported concomitant disease; in one other young dog with chronic renal failure; and in four older dogs with leishmaniosis $(n=1)$, immunosuppression $(n=2)$ or post splenectomy $(\mathrm{n}=1)$ [51]. 
Table 3: Signalment, clinical signs and vector-borne agents in nine co-infected dogs.

\begin{tabular}{|c|c|c|c|c|c|c|c|c|}
\hline Agents & Gender & Breed & $\begin{array}{l}\text { Age } \\
\text { (months) }\end{array}$ & $\begin{array}{l}\text { Clinical } \\
\text { signs }\end{array}$ & HCT (\%) & Ticks & Month & $\begin{array}{l}\text { Clinical } \\
\text { outcome } \\
\text { (imidocarb } \\
\text { treatment) }\end{array}$ \\
\hline \multirow{6}{*}{$\begin{array}{l}\text { B. canis canis } \\
\text { and } L \text {. } \\
\text { infantum }\end{array}$} & $\mathrm{F}$ & Dalmatian & 72 & ND & ND & No & October & Recovered \\
\hline & M & Mongrel & 02 & $\begin{array}{l}\text { Hyperthermi } \\
\text { a, PMM, RU }\end{array}$ & 20 & Yes & November & Died \\
\hline & M & Mongrel & 02 & ND & 10 & Yes & November & Recovered \\
\hline & $\mathrm{F}$ & Mongrel & 36 & ND & 40 & Yes & February & Recovered \\
\hline & M & Mongrel & 36 & $\begin{array}{l}\text { Hyperthermi } \\
a, R U\end{array}$ & 40 & Yes & February & Recovered \\
\hline & M & Mongrel & ND & PMM, RU & 15 & Yes & March & Recovered \\
\hline $\begin{array}{l}\text { B. canis canis } \\
\text { and } H \text {. canis }\end{array}$ & $\mathrm{F}$ & Podengo & 47 & $\begin{array}{l}\text { Hyperthermi } \\
\text { a, PMM, RU }\end{array}$ & 25 & Yes & May & Recovered \\
\hline $\begin{array}{l}\text { B. canis canis } \\
\text { and E. canis }\end{array}$ & M & $\begin{array}{l}\text { German } \\
\text { pointer }\end{array}$ & 78 & $\begin{array}{l}\text { Anorexia, } \\
\text { hyperthermia } \\
\text {, lethargy, RU }\end{array}$ & 40 & No & March & Recovered \\
\hline $\begin{array}{l}\text { B. canis } \\
\text { vogeli, E. canis } \\
\text { and } L . \\
\text { infantum }\end{array}$ & M & Podengo & 36 & $\begin{array}{l}\text { Anorexia, } \\
\text { hypothermia, } \\
\text { lethargy, } \\
\text { YMM }\end{array}$ & 03 & Yes* & April & Died \\
\hline
\end{tabular}

F: female; HCT: haematocrit (normal range: 37-55\%); M: male; ND: not determined; PMM: pale mucous membranes; RU: red urine; YMM: yellow mucous membranes. ${ }^{*} R$. sanguineus.

In the present study, co-infection with L. infantum was more prevalent (16\%) than with E. canis (4\%) or $H$. canis (2\%) among the 45 dogs with babesiosis. Due to relatively lower parasite loads of Leishmania in the blood, compared with other tissues, use of blood to assess infection with Leishmania may have limited the sensitivity of detection; however, the use of highly sensitive quantitative real time PCR for Leishmania spp. in this study probably improved the prospects of detection, when compared with conventional PCR assays [49,52]. In the present study, large babesial piroplasms were detected in blood smears of nearly $90 \%$ of the clinically suspected dogs further confirmed as infected with B. canis canis or $B$. canis vogeli. Parasites were not detected in the smears of four dogs found infected with B. canis canis and diagnosed by PCR and sequencing. Microscopy may lack sensitivity in dogs clinically suspected of babesiosis, possibly due to low parasitaemia [2,7].

The arthropods described as vectors of the detected pathogens - D. reticulatus for B. canis canis; Phlebotomus spp. for L. infantum; and R. sanguineus for B. canis vogeli, E. canis, and H. canis - are present in northern Portugal
$[37,39]$. In this study, Dermacentor spp. were found on dogs infected with $B$. canis canis and $R$. sanguineus on one dog co-infected with B. canis vogeli and E. canis (and also $L$. infantum). History of travel outside this area, where canine leishmaniosis and babesiosis are endemic, was not obtained for any of the dogs. This situation supports the assumption that infections with Babesia, Leishmania and the other vector-borne agents were acquired locally.

The only dog found infected with B. canis vogeli in our study also had co-infection with $E$. canis and L. infantum. It is possible that chronic subclinical or acute infection with $B$. canis vogeli had been made clinically apparent by these co-infections. We had previously detected one clinical case in a $\operatorname{dog}$ from northern Portugal infected with $B$. canis vogeli concurrently with $A$. platys [36]. Babesia canis vogeli and $E$. canis share the same vector species, i.e. $R$. sanguineus ticks. The co-infected dog may have been exposed to arthropods infected with single pathogen species at different points in time or to vector(s) concurrently infected with multiple agents [1]. Co-infections with Leishmania and tick-borne organisms may affect the 


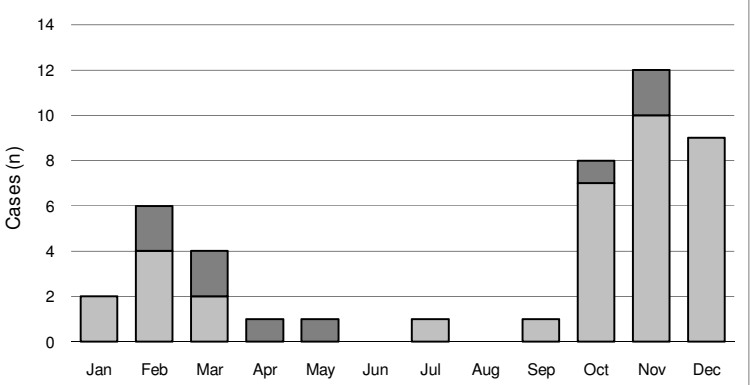

Figure 1 Monthly distribution of canine babesiosis and of co-infection cases in $\mathbf{4 5}$ dogs from northeastern Portugal. Light grey bars represent 36 cases of babesiosis with no co-infecting agents (Anaplasma/Ehrlichia, Hepatozoon or Leishmania). All 36 dogs infected solely with Babesia had B. canis canis infection. Dark grey bars represent nine cases of babesiosis with one or two concurrent infecting agents along with $B$. canis canis $(n=8)$ or $B$. canis vogeli $(n=1)$, respectively.

severity of CVBD and the variety of associated clinical signs [53]. In a study with beagle dogs naturally exposed to $E$. canis and $L$. infantum, the frequency of clinical signs (lymphadenomegaly, splenomegaly, epistaxis, onychogryposis, dermatits and weight loss) was significantly different between animals with dual infection and those with single infection [54]. However, the clinical signs of coinfections with two or more vector-borne organisms are often difficult to be specifically assigned to each one of the infecting agents [55]. In the present study, although a complete clinicopathological evaluation was not performed, especially blood cell counts, no significant differences among HCT values were found between the coinfected dogs and those with one single infection detected. Nevertheless, dogs with co-infections had a lower survival rate when compared to those with single infection. In fact, two dogs (22\%) died out of the nine found co-infected: one with B. canis vogeli, E. canis and $L$. infantum, and the other one with $B$. canis canis and $L$. infantum infection. From the 36 dogs found infected only with $B$. canis canis, two (6\%) were euthanized and the remaining 34 animals (94\%) clinically recovered with the anti-babesial treatment.

Another study in rural and hunting dogs $(\mathrm{n}=473)$, from northeastern Portugal, showed a $15 \%$ seroprevalence of antibodies to E. canis, and a $2 \%$ prevalence of Hepatozoon spp. in blood smears [40]. Six dogs were simultaneously found to be seropositive for E. canis and positive for Hepatozoon spp., but PCR did not detect Ehrlichia or Anaplasma in any of those animals. Nevertheless, E. canis DNA was sequenced from four other dogs, thus revealing a $0.9 \%$ prevalence of infection. No babesial piroplasms were found in blood smears from all the dogs included in the same study. The differences between these prevalence rates for $E$. canis, as detected by molecular methods, and piroplasms and those observed in the present study may be explained by a different sample population and the methods used. In fact, only $10 \%$ of the dogs studied by Figueiredo [40] were clinically suspected of bacterial or protozoal diseases, and infection with Babesia spp. was not assessed molecularly by this author, whereas all the dogs in the present study were positive to Babesia spp. and thus exposed to at least one species of tick-borne pathogen.

In this study, two littermates aged two months old were both found co-infected with B. canis canis and L. infantum. This finding could suggest the possibility of transplacental transmission of L. infantum [56] and/or B. canis canis [57]. However, both puppies were found infested with ticks (species not identified), which should be regarded as the most likely source of transmitting Babesia to them. Regarding infection with Leishmania, these animals were born in early October and transmission by phlebotomine sand flies should still be considered [37]. Data on physical examination were not available for one of the dogs. The other dog presented hyperthermia, pale mucous membranes and red urine, which could be attributed to B. canis canis infection. Both animals suffered from anaemia, and one of the dogs died. It is not clear whether infection with L. infantum contributed to the clinical abnormalities in these two puppies and whether they were suffering from pathological effects of infection with Leishmania. Other tests, including serological analysis for antibodies to Leishmania, complete blood count, serum biochemistry panel and urinalysis, could have been helpful in clarifying the clinical status of these two and of the other seven co-infected dogs as well [58]. In general, the incubation period of canine babesiosis is short (4-21 days) [3], while the incubation of canine leishmaniosis is much longer (2 months to several years) [59].

The trend of canine babesiosis seasonality found in the present study is further strengthened by results from an additional study (Diz-Lopes D, Rodrigues FT: Babesiose canina - estudo clínico no Nordeste Transmontano [unpublished abstract]. V Congresso Veterinário Montenegro: 17-18 January 2009; Porto). A higher occurrence of disease was found during October and November (21 cases during each month) in 98 dogs from northeastern Portugal diagnosed with babesiosis by clinical examination and by observation of intraerythrocytic large piroplasms, from January 2005 to December 2008. Considerable numbers of canine babesiosis cases were also found from December to May, with monthly values ranging between $6 \%$ and $11 \%$. Sixty-two per cent of all the cases were detected in hunting dogs, and $52 \%$ of all the affected animals were Podengo dogs (Diz-Lopes D, Rodrigues FT: Babesiose canina - estudo clínico no Nordeste Transmontano [unpublished abstract]. V Congresso Veterinário Montenegro: 17-18 January 2009; Porto). In the present study, it was found that approxi- 
mately $90 \%$ of the 45 cases of babesiosis in dogs from northern Portugal were diagnosed in October (18\%), November (27\%), December (20\%), February (13\%) and March (9\%), i.e. autumn and winter months. In central Europe, the occurrence of canine babesiosis due to $B$. canis has been found to change in an annual seasonal pattern, although exact time of beginning and ending of Dermacentor spp. activity is strongly correlated with specific local climate conditions [60]. In fact, epidemiological and clinical surveillance studies are needed for mapping the risk of babesiosis and other CVBD in different geographical regions.

A study in urban and rural dogs $(n=651)$ from Hungary revealed a $6 \%$ seropositivity to $B$. canis [61]. Seroprevalence to $B$. canis was significantly different for German shepherd and Komondor dogs, suggesting a genetic predisposition to chronic subclinical infection (carrier state) with long-term maintenance of seropositivity. A higher prevalence of specific antibodies in three out of four Komondors, a local breed, was explained by an increased risk of them having unnoticed ticks attached to their heavy hair coat [61]. In the present study, B. canis canis was found in males and females, younger and older dogs, from nine defined breeds and particularly from mongrels. There was no clear distinction of age and sex between single-infected and co-infected dogs. When comparing the proportions of co-infected mongrel dogs $(\sim 38 \%)$ and that of co-infected defined breed animals $(\sim 11 \%)$, there was a quantitative but not significant difference. Mongrels, Podengo and Brittany dogs represented the larger part of those found affected by babesiosis. Rather than a genetic or breed predisposition, this situation probably reflects the fact that these dog breeds and crosses are popular and over-represented in northern Portugal. Furthermore, a considerable percentage of these dogs live outdoors and are used for hunting activities in the field, where they face a higher risk of contacting with infected arthropod vectors.

Theleria annae may cause severe illness in dogs, including renal failure, and is endemic in northwestern Spain [21], which borders part of the area where the present study was carried out. To our knowledge, there are no written reports of autochthonous canine T. annae infection in Portugal. Nevertheless, due to the increasing mobility of dogs and the existence of competent or presumptive vectors, piroplasms may spread into nonendemic areas $[1,2]$.

\section{Conclusions}

In conclusion, this study confirmed the presence of $B$. canis canis and B. canis vogeli as agents of babesiosis in dogs from northern Portugal, with a large majority of the clinical cases found with the former piroplasm. A higher sensitivity of Babesia spp. detection was obtained by use of PCR assays, compared to microscopy of blood smears. Co-infections with some other vector-borne agents were also detected and molecularly characterized, namely $L$. infantum, E. canis and H. canis. Detection and identification of species and subspecies of pathogens, either in single or in co-infection, are necessary for the treatment, clinical management and prevention of CVBD.

\section{Competing interests}

The authors declare that they have no competing interests.

\section{Authors' contributions}

Conceived and design the study: LC, YYM and GB. Collected and characterized clinical samples: FTR, AC, JM and DDL. Performed PCR and genetic analysis: YYM. Analyzed data, drafted and revised the manuscript: LC and GB. All authors gave final approval of the version to be submitted.

\section{Acknowledgements}

The authors thank Dr. Joana Tuna and Dr. Lisete Vieira, from Clínica Veterinária Os Bichos, Dr. Dalit Talmi-Frank, from the Hebrew University, and the Board and the Staff of the Veterinary Teaching Hospital, University of Trás-os-Montes e Alto Douro, for their assistance. Publication of the thematic series has been sponsored by Bayer Animal Health GmbH.

\section{Author Details}

'Department of Veterinary Sciences, University of Trás-os-Montes e Alto Douro, Vila Real, Portugal, 2 Parasite Disease Group, Instituto de Biologia Molecular e Celular, Universidade do Porto, Portugal, ${ }^{3}$ School of Veterinary Medicine, Hebrew University of Jerusalem, Rehovot, Israel, ${ }^{4}$ Clínica Veterinária Dr. Duarte Diz-Lopes, Bragança, Portugal and ${ }^{5}$ Clínica Veterinária Os Bichos, Chaves, Portugal

Received: 5 February 2010 Accepted: 8 April 2010

Published: 8 April 2010

\section{References}

1. Otranto D, Dantas-Torres F, Breitschwerdt EB: Managing canine vectorborne diseases of zoonotic concern: part one. Trends Parasitol 2009, 25:157-163.

2. Otranto D, Dantas-Torres F, Breitschwerdt EB: Managing canine vectorborne diseases of zoonotic concern: part two. Trends Parasitol 2009, 25:228-235.

3. Boozer AL, Macintire DK: Canine babesiosis. Vet Clin Small Anim 2003, 33:885-904.

4. Lobetti RG: Canine babesiosis. Compend Cont Educ Pract Vet 1998 20:418-431.

5. Bourdoiseau G: Canine babesiosis in France. Vet Parasitol 2006 138:118-125.

6. Brandão LP, Hagiwara MK, Myiashiro SI: Humoral immunity and reinfection resistance in dogs experimentally inoculated with Babesia canis and either treated or untreated with imidocarb dipropionate. Vet Parasitol 2003, 114:253-265.

7. Irwin P: Canine babesiosis: from molecular taxonomy to control. Parasites Vect 2009, 2(Suppl 1):S4.

8. Uilenberg G, Franssen FFJ, Perie M, Spanjer AMM: Three groups of Babesia canis distinguished and a proposal for nomenclature. Vet $Q$ 1989, 11:33-40.

9. Zahler M, Schein E, Rinder H, Gothe R: Characteristic genotypes discriminate between Babesia canis isolates of differing vector specificity and pathogenicity to dogs. Parasitol Res 1998, 84:544-548.

10. Cacciò SM, Antunovic B, Moretti A, Mangili V, Marinculic A, Baric RR, Slemenda SB, Pieniazek NJ: Molecular characterisation of Babesia canis canis and Babesia canis vogeli from naturally infected European dogs. Vet Parasitol 2002, 106:285-292.

11. Solano-Gallego L: Update on canine babesiosis: the European perspective. In Proceedings of the 4th Symposium of the CVBD World Forum: 25-28 March 2009; Seville Bayer Animal Health. Leverkusen:30-33. 
12. Matjila TP, Penzhorn BL, Bekker CPJ, Nijhof AM, Jongejan F: Confirmation of occurrence of Babesia canis vogeli in domestic dogs in South Africa. Vet Parasitol 2004, 122:119-125.

13. Inokuma H, Yoshizaki Y, Matsumoto K, Okuda M, Onishi T, Nakagome K, Kosugi R, Hirakawa M: Molecular survey of Babesia infection in dogs in Okinawa, Japan. Vet Parasitol 2004, 121:341-346.

14. Jefferies R, Ryan UM, Muhlnickel CJ, Irwin PJ: Two species of canine Babesia in Australia: detection and characterization by PCR. J Parasitol 2003, 89:409-412.

15. Birkenheuer AJ, Correa MT, Levy MG, Breitschwerdt EB: Geographic distribution of babesiosis among dogs in the United States and association with dog bites: 150 cases (2000-2003). J Am Vet Med Assoc 2005, 227:942-947.

16. Passos LMF, Geiger SM, Ribeiro MFB, Pfister K, Zahler-Rinder M: First molecular detection of Babesia vogeli in dogs from Brazil. Vet Parasitol 2005, 127:81-85.

17. Sasaki M, Omobowale O, Tozuka M, Ohta K, Matsuu A, Nottidge HO, Hirata $\mathrm{H}$, Ikadai H, Oyamada T: Molecular survey of Babesia canis in dogs in Nigeria. J Vet Med Sci 2007, 69:1191-1193.

18. Birkenheuer AJ, Neel J, Ruslander D, Levy MG, Breitschwerdt EB: Detection and molecular characterization of a novel large Babesia species in a dog. Vet Parasitol 2004, 124:151-160

19. Sikorski LE, Birkenheuer AJ, Holowaychuk MK, McCleary-Wheeler AL, Davis $J M$, Littman MP: Babesiosis caused by a large Babesia species in 7 immunocompromised dogs. JVet Intern Med in press.

20. Zahler M, Rinder $\mathrm{H}$, Schein $\mathrm{E}$, Gothe R: Detection of a new pathogenic Babesia microti-like species in dogs. Vet Parasitol 2000, 89:241-248.

21. Camacho-García AT: Piroplasma infection in dogs in northern Spain. Vet Parasito/ 2006, 138:97-102

22. Criado-Fornelio A, Gónzalez-del-Río MA, Buling-Saraña A, Barba-Carretero JC: Molecular characterization of a Babesia gibsoni isolate from a Spanish dog. Vet Parasitol 2003, 117:123-129.

23. Hartelt K, Rieker T, Oehme RM, Brockmann SO, Müller W, Dorn N: First evidence of Babesia gibsoni (Asian genotype) in dogs in Western Europe. Vector Borne Zoonotic Dis 2007, 7:163-166.

24. Beck R, Vojta L, Mrljak V, Marinculić A, Beck A, Živičnjak T, Cacciò SM: Diversity of Babesia and Theileria species in symptomatic and asymptomatic dogs in Croatia. Int J Parasitol 2009, 39:843-848

25. Yeagley TJ, Reichard MV, Hempstead JE, Allen KE, Parsons LM, White MA, Little SE, Meinkoth JH: Detection of Babesia gibsoni and the canine small Babesia 'Spanish isolate' in blood samples obtained from dogs confiscated from dogfighting operations. J Am Vet Med Assoc 2009, 235:535-539.

26. Trapp SM, Messick JB, Vidotto O, Jojima FS, de Morais HS: Babesia gibsoni genotype Asia in dogs from Brazil. Vet Parasitol 2006, 141:177-180.

27. Muhlnickel CJ, Jefferies R, Morgan-Ryan UM, Irwin PJ: Babesia gibsoni infection in three dogs in Victoria. Aust Vet J 2002, 80:606-610.

28. Kjemtrup AM, Wainwright K, Miller M, Penzhorn BL, Carreno RA: Babesia conradae, sp. Nov., a small canine Babesia identified in California. Vet Parasitol 2006, 138:103-111.

29. Criado-Fornelio A, Martinez-Marcos A, Buling-Saraña A, Barba-Carretero JC: Molecular studies on Babesia, Theileria and Hepatozoon in southern Europe. Part I. Epizootiological aspects. Vet Parasitol 2003, 113:189-201.

30. Criado A, Martinez J, Buling A, Barba JC, Merino S, Jefferies R, Irwin PJ: New data on epizootiology and genetics of piroplasms based on sequences of small ribosomal subunit and cytochrome b genes. Vet Parasitol 2006, 142:238-247.

31. Matjila PT, Leisewitz AL, Oosthuizen MC, Jongejan F, Penzhorn BL: Detection of a Theileria species in dogs in South Africa. Vet Parasitol 2008, 157:34-40.

32. Gray JS, Dautel H, Estrada-Peña A, Kahl O, Lindgren E: Effects of climate change on ticks and tick-borne diseases in Europe. Interdiscip Perspect Infect Dis 2009 in press.

33. Diz-Lopes D, Rodrigues FT, Alves S, Santos-Silva M: Babesiose em Cão de Gado Transmontano. Vet Tec 2005, 11(Set/Out):36.

34. Cardoso L, Costa A, Tuna J, Vieira L, Eyal O, Yisaschar-Mekuzas Y, Baneth G: Babesia canis canis and Babesia canis vogeli infections in dogs from northern Portugal. Vet Parasitol 2008, 156:199-204.

35. Abranches P, Sampaio-Silva ML, Santos-Gomes GM, Avelino IC, Conceição-Silva FM, Seixas-Lopes A, Silva-Pereira MCD, Janz JG: Kala-azar in Portugal. VII. Epidemiological survey in Alijó (endemic region of Alto-Douro). Res Rev Parasitol 1992, 52:121-124.
36. Cardoso L, Tuna J, Vieira L, Yisaschar-Mekuzas Y, Baneth G: Molecular detection of Anaplasma platys and Ehrlichia canis in dogs from the North of Portugal. Vet J 2008, 183:232-233.

37. Alves-Pires $\mathrm{C}$, Ribeiro H: The phlebotomine sandflies of Portugal. V. Observations on the ecology of the vectors of leishmaniasis in the Alto Douro region. Parassitologia 1991, 33(Suppl 1):63-68.

38. Caeiro VMP: As carraças em Portugal: seus hospedeiros domésticos e silvestres. Ciclos vitais, preferências de vegetação e clima. Med Vet 1992, 28:7-25

39. Santos-Silva M, Sousa R, Santos AS, Lopes D, Queijo E, Doreta B, Vitorino L, Bacellar F: Ticks and tick-borne rickettsiae surveillance in Montesinho Natural Park, Portugal. Ann NY Acad Sci 2006, 1078:137-142.

40. Figueiredo TCD: Estudo da prevalência de doenças associadas a vectores em canídeos domésticos do distrito de Bragança. In MSC dissertation Lisbon University, Faculty of Medicine; 2008.

41. Shaw SE, Day MJ, Birtles RJ, Breitschwerdt EB: Tick-borne infectious diseases of dogs. Trends Parasitol 2001, 17:74-80.

42. Baneth G, Samish M, Shkap V: Life cycle of Hepatozoon canis (Apicomplexa: Adelorina: Hepatozoidae) in the tick Rhipicephalus sanguineus and domestic dog (Canis familiaris). J Parasitol 2007. 93:283-299.

43. Strauss-Ayali D, Jaffe CL, Burshtain O, Gonen L, Baneth G: Polymerase chain reaction using noninvasively obtained samples, for the detection of Leishmania infantum DNA in dogs. J Infect Dis 2004, 189:1729-1733.

44. Olmeda AS, Armstrong PM, Rosenthal BM, Valladares B, del Castillo A, de Armas F, Miguelez M, Gonzalez A, Rodriguez JA, Spielman A, Telford SR: A subtropical case of human babesiosis. Acta Trop 1997, 67:229-234.

45. Brown GK, Canfield PJ, Dunstan RH, Roberts TK, Martin AR, Brown CS, Irving R: Detection of Anaplasma platys and Babesia canis vogeli and their impact on platelet numbers in free-roaming dogs associated with remote Aboriginal communities in Australia. Aust Vet J 2006, 84:321-325

46. Gal A, Loeb E, Yisaschar-Mekuzas Y, Baneth G: Detection of Ehrlichia canis by PCR in different tissues obtained from dogs surveyed for naturally occurring canine monocytic ehrlichiosis. Vet J 2008, 175:212-217.

47. Inokuma H, Okuda M, Ohno K, Shimoda K, Onishi T: Analysis of the $18 \mathrm{~S}$ rRNA gene sequence of a Hepatozoon detected in two Japanese dogs. Vet Parasitol 2002, 106:265-271.

48. Rubini AS, Paduan KS, Cavalcante GG, Ribolla PE, O'Dwyer LH: Molecular identification and characterization of canine Hepatozoon species from Brazil. Parasitol Res 2005, 97:91-93

49. Talmi-Frank D, Nasereddin A, Schnur LF, Schönian G, Özensoy S, Jaffe CL, Baneth G: Detection and identification of Old World Leishmania by high resolution melt analysis. PLoS Negl Trop Dis 2010, 4:e581.

50. Petrie A, Watson P: Statistics for Veterinary and Animal Science Oxford: Blackwell; 1999.

51. Solano-Gallego L, Trotta M, Carli E, Carcy B, Caldin M, Furlanello T: Babesia canis canis and Babesia canis vogeli clinicopathological findings and DNA detection by means of PCR-RFLP in blood from Italian dogs suspected of tick-borne disease. Vet Parasitol 2008, 157:211-221.

52. Francino O, Altet L, Sánchez-Robert E, Rodriguez A, Solano-Gallego L, Alberola J, Ferrer L, Sánchez A, Roura X: Advantages of real-time PCR assay for diagnosis and monitoring of canine leishmaniosis. Vet Parasitol 2006, 137:214-221.

53. Tabar MD, Francino O, Altet L, Sánchez A, Ferrer L, Roura X: PCR survey of vectorborne pathogens in dogs living in and around Barcelona, an area endemic for leishmaniosis. Vet Rec 2009, 164:112-116.

54. Mekuzas Y, Gradoni L, Oliva G, Foglia Manzillo V, Baneth G: Ehrlichia canis and Leishmania infantum co-infection: a 3-year longitudinal study in naturally exposed dogs. Clin Microbiol Infect 2009 in press.

55. Kordick SK, Breitschwerdt EB, Hegarty BC, Southwick KL, Colitz CM, Hancock SI, Bradley JM, Rumbough R, McPherson JT, MacCormack JN: Coinfection with multiple tick-borne pathogen in a Walker Hound kennel in North Carolina. J Clin Microbiol 1999, 37:2631-2638.

56. Rosypal AC, Troy GC, Zajac AM, Frank G, Lindsay DS: Transplacental transmission of a North American isolate of Leishmania infantum in an experimentally infected beagle. J Parasitol 2005, 91:970-972.

57. Fukumoto $S$, Suzuki H, Igarashi I, Xuan X: Fatal experimental transplacental Babesia gibsoni infections in dogs. Int J Parasitol 2005, 35:1031-1035. 
58. Miró G, Cardoso L, Pennisi MG, Oliva G, Baneth G: Canine leishmaniosis new concepts and insights on an expanding zoonosis: part two. Trends Parasitol 2008, 24:371-377.

59. Slappendel R: Canine leishmaniasis. A review based on 95 cases in the Netherlands. Vet Q 1988, 10:1-16.

60. Leschnik M, Kirtz G, Tichy A, Leidinger E: Seasonal occurrence of canine babesiosis is influenced by local climate conditions. Int J Med Microbiol 2008, 298(S1):243-248.

61. Hornok S, Edelhofer R, Farkas R: Seroprevalence of canine babesiosis in Hungary suggesting breed predisposition. Parasitol Res 2006, 99:638-642.

doi: 10.1186/1756-3305-3-27

Cite this article as: Cardoso et al., Canine babesiosis in northern Portugal and molecular characterization of vector-borne co-infections Parasites \& Vectors 2010, 3:27

Submit your next manuscript to BioMed Central and take full advantage of:

- Convenient online submission

- Thorough peer review

- No space constraints or color figure charges

- Immediate publication on acceptance

- Inclusion in PubMed, CAS, Scopus and Google Scholar

- Research which is freely available for redistribution

Submit your manuscript at www.biomedcentral.com/submit 